\title{
Fuarların Uluslararası Pazarlar Açısından Önemi: Turizm İşletmeleri Üzerine Bir Araştırma*
} (Araştırma Makalesi)

The Importance of Fairs in Terms of International Markets: A Research on Tourism Enterprises

Doi: 10.29023/alanyaakademik.550708

Ömer Zafer GÜVEN

Dr. Ögr. Üyesi, Dumlupınar Üniversitesi

omerzafer.guven@dpu.edu.tr

Orcid No: 0000-0001-7956-6100

\section{Tuba CEYLAN}

tuba.ceylan1982@gmail.com

Orcid No: 0000-0001-5312-6932

Bu makaleye atıfta bulunmak için: Güven, Ö.Z., Ceylan T. (2019). Fuarların Uluslararası Pazarlar Açısından Önemi: Turizm Işsletmeleri Üzerine Bir Araştırma. Alanya Akademik Bakış, 3(3), Sayfa No. 277-294.

\section{Anahtar kelimeler: \\ Fuar, Uluslararasi \\ Pazar, Turizm \\ İsletmeleri}

Makale Geliş Tarihi: 05.09.2019

Kabul Tarihi:

11.09.2019

\section{ÖZET}

$\overline{\text { Uluslararası fuar organizasyonları günümüz globalleşen dünyasında }}$ uluslararası pazara açılmada önemli organizasyonlardır. Tüm sektörlerde olduğu gibi turizm sektöründe de turizm işletmeleri (konaklama işletmeleri, seyahat acentalar, havayolu işletmeleri ve yiyecek içecek işletmeleri) mevcut pazarlarını korumak ve yeni pazarlara açılmak için fuar organizasyonlarına katılmaktalar. Bu çalışmada turizm işletmelerinin uluslararası fuarlara katılım amaçları incelenmiştir. Araştırmada 2017 Travel Turkey İmir fuarına katılan turizm işletmeleri yöneticilerine anket uygulaması yapılmiştır. 70 turizm işletmesinden toplanan veriler bir istatistik veri analiz programı yardımıyla analiz edilmiştir. Araştırma sonuçlarına göre turizm işletmelerinin uluslararası fuarlara öncelikli katılım amaçlarının Müşteri/Bayi Ağı Genişletme ve Ürün ve Hizmet Tanıtımı olduğu görülmektedir. Buna ek olarak turizm işletmelerinin faaliyet alanları ile fuarlara katılım amaçları arasında anlamlı farklılıklar olmadiğ sonucuna ulaşılmıştır.

\begin{abstract}
International fair organizations are important organizations in opening up the international market in today's globalizing world. As in all sectors, tourism enterprises (accommodation enterprises, travel agencies, airline companies and food and beverage enterprises) participate in fair organizations to protect their existing markets and to open up new markets. In this study, the purpose of tourism enterprises to participate in international fairs was examined. In this research, a survey was applied to the managers of tourism enterprises participating in the 2017 Travel Turkey Izmir Fair. The data collected from 70 tourism enterprises were analyzed
\end{abstract}

Keywords:

Fairs, International Market, Tourism Enterprises 
with the help of a statistical data analysis program. According to the results of the research, it is seen that the priority objectives of tourism enterprises to participate in international fairs are Customer / Dealer Network Expansion and Product and Service Promotion. In addition, it has been concluded that there are no significant differences between the fields of activity of tourism enterprises and the purposes of participation in fairs

\footnotetext{
Bu makale Dumlupınar Üniversitesi Sosyal Bilimler Enstitüsü Uluslararası Ticaret ve Finansman Ana Bilim Dalında Dr. Öğr.Üyesi Ömer Zafer GÜVEN danışmanlığında Tuğba Ceylan tarafından yazılan aynı isimli tezden üretilmiştir.
}

\section{GİRIŞ}

Uluslararası fuarlar hem ülkelerin hem de işletmelerin pazarlama ve ticaret faaliyetlerinde oldukça önemli bir rol oynamaktadır. Uluslararası fuarlara katılan işletmeler bu sayede ürün ve hizmetlerini daha geniş kitlelere tanıtma firsatı yakalamak ve yeni iş ortakları ve yeni pazarlar bulmaktadırlar.

Kendi ülkesi dışında uluslararası alanda da faaliyet göstermek isteyen işletmeler için fuarlar geniş kitlelere ve yeni pazarlara ulaşmanın en uygun yollarından birisidir. Fuarlar bu amaç doğrultusunda düşünen birçok işletmeyi ve bulundukları sektöre yön veren markaları bir araya getirmektedir. Küçük-orta ve büyük çaplı işletmeler fuarlar sayesinde birbirlerini tanımaktadırlar. Bunun bir sonucu olarak da uluslararası pazarda rekabette diğer işletmelere göre avantaj yakalamaktadırlar.

Uluslararası pazar girişi işletmeler açısından kolaylaştıran fuar organizasyonları sayesinde işletmeler, uluslararası arenada ürün ve hizmetlerinin tanıtımını kolaylıkla yapabilmekte ve hem hedef müşteri kitlesine, hem de yurtdışındaki ilgili işletmelere ürün ve hizmetlerini ayrıntılı bir şekilde anlatma firsatı bulmaktadırlar. Fuarlara katılan işletmeler ürün ve hizmetlerini doğrudan satış imkânı yakalarken, aynı şekilde ürün ve hizmetlerinin diğer ülkelerde satışını yapabilecek müşteri ve bayi ağını da sağlayabilmektedirler. Uluslararası fuarlar, katılımcı işletmelere bir yandan rakiplerinin analizini yapma imkânı sağlarken, diğer yandan ürün ve hizmetleri ile ilgili inovatif gelişmeleri ve yeni trendleri takip etme imkânı da sağlamaktadır. Benzer şekilde bu fuarlar sayesinde katılımcı işletmeler kurumsal itibar ve marka itibarı kazanma imkânı da bulmaktadırlar.

Günümüzde giderek artan rekabet ortamında işletmeler fuar organizasyonlarına daha sık katılmakta ve rekabette rakiplerine avantaj sağlamaya çalışmaktadırlar. İşletmelerin pazarlama faaliyetleri içerisinde önemli bir yer tutan ulusal ve uluslararası fuarlar, işletmeler açısından birçok avantaj sağlamaktadır. Bu açıdan fuarlara katılan turizm işletmelerinin fuarlara katılım amaçları, beklentileri ve fuar sonrası kazanımları incelenmesi gerekli bir konudur. $\mathrm{Bu}$ araştırmada uluslararası fuarlara katılan turizm işletmelerinin fuarlara katılım amaçları ve fuarlara bakış açıları incelenmiş ve işletmelerin ürün ve hizmet tanıtımı, doğrudan satış, müşteri ağını genişletme, rakiplerin analizi, kurumsal itibar kazanma ve yenilik takibi konularında fuarları değerlendirmeleri ele alınarak, bu değerlendirmelerin analizi yapılmıştır. 


\section{FUARIN TANIMI VE TÜRLERI}

Fuar "alıcı ile satıcının belirli bir işi yapmak için bir araya geldikleri geçici bir pazar" olarak tanımlanmıştır (Toker,2007:423). TOBB’un 03 Kasım 2014 tarihli ve 94 sayılı kararına istinaden yurtiçinde fuar düzenlenmesine dair usul ve esaslarda fuarı; "Standlar kurulması yoluyla, ticarete konu olan mal ve hizmetlerin, bunlar ile ilgili teknolojik gelişme, bilgi ve yeniliklerin tanıtımını ve aktarımını amaçlayan, ziyaretçi ve katılımcı arasında bilgi alışverişi, işbirliği, pazar büyütmeye ve geleceğe yönelik ticari ilişkilerin kurulması ve geliştirilmesi için bu esaslarda belirlenen niteliklere uygun alanlarda düzenlenen, konusunu oluşturduğu alanın, sektörün ve toplumun menfaatlerini gözeten, düzenleyicisi, adı, türü, yeri, konusu, tarihi ve süresi önceden belirlenen etkinlikler" olarak tanımlanmıştır (www.tobb.org.tr, 2018).

Fuarlar ulaşılması hedeflenen kitlenin coğrafyasına göre ve düzenleme amacına göre iki şekilde sınıflandırılmaktadır.

Ulaşılması hedeflenen kitlenin coğrafyasına göre fuar türleri bölgesel, ulusal ve uluslararası olmak üzere üç başlık altında incelenebilir.

Bölgesel Fuarlar; Bir bölge içerisindeki organize edilen fuarlardır. Çok geniş kitlelere hitap etmese de tüm fonksiyonlarıyla fuarların temel kurallarına uygun olarak düzenlenirler. Bu fuarlar düzenlenirken genellikler fuar ismi içerisinde bölge ismi belirtilir. Örneğin, Orta Anadolu Kayseri Fuarı ve Karadeniz Samsun Fuarı gibi (Aymankuy, 2006: 188).

Ulusal Fuarlar; genellikle diğer ülkelere de açık olmakla birlikte, tüm ülke vatandaşlarını hedef kitle olarak belirleyen fuarlardır. Ulusal fuarlar genellikle fuarın yapıldığ 1 yerin ismini alırlar ve ülke genelinde geleneksel, sosyal ve ekonomik birer faaliyet özelliği taşırlar (Aymankuy, 2006: 188).

Uluslararası Fuarlar; Uluslararası fuarlar yapı olarak globalleşmiş bir özellik taşır ve ulusal boyutta katılımcı ve ziyaretçilere açık olmakla birlikte, uluslararası boyutta da katılımcı ve ziyaretçi almaktadır. Uluslararası fuarların, katılımcıların beklentilerini karşılaması için uluslararası boyuttaki şirketlerinde bu fuarlara katılması gerekmektedir. Hem ulusal hem de uluslararası piyasadaki işletmeleri bir araya getiren bu fuarlar, işletmelerin global olarak rakiplerini incelemesini ve yeni pazarlar ve hedef kitleler kazanmasını sağlamaktadır (Aymankuy, 2006: 188-189).

Düzenleme amacına göre fuarlar ise Genel Fuarlar, Ticari İhtisas Fuarları, Entegre Fuarlar ve Tüketici Fuarları olmak üzere 5 başlık altında ele alınmaktadır.

Genel Fuarlar; belirli bir sektörü veya ürün grubunu esas almaksızın, çeşitli mal ve hizmetlerin beraber sergilendiği ve bunların ticari tanıtımının yapıldığı, içinde sosyal ve kültürel etkinliklerin de bulunabileceği, en az elli katılımcının yer aldığ 1 , süresi on beş günü geçmeyen etkinliklerdir. Genel fuarlarda belli bir ürün ya da hizmet yoktur. Tüm sektörler aynı fuarda yer alabilmektedir. Aynı fuarda kitaplardan, mobilya ürünlerine kadar pek çok ürün görülebilmektedir. Bu tip fuarlara verilebilecek en iyi örneklerden birisini İzmir Enternasyonal fuarıdır. Bu fuarlar her yaştan insana açık olmalarından dolayı çok fazla ziyaretçiye ev sahipliği yaparlar (Kaçar, 2013: 16).

Ticari İhtisas Fuarlarl; yalnızca düzenlendiği konuda üretilen malların sergilenmesine izin veren, geniş halk kitlelerinden ziyade işadamlarını yüz yüze getiren daha dar kapsamlı fuarlardır. Gıda İhtisas Fuarı, Sanayi İhtisas Fuarı gibi (https://www.muhasebeturk.org/ 
nedir/ihtisas-fuari-nedir-ne-demek 2018). İşletmeler hem tanıtım hem de pazarlama aktivitelerini bu fuarlar sayesinde eş zamanlı olarak yürütebilmektedirler. Ticari ihtisas fuarları, belirlenmiş bir zaman ve mekân içerisinde üretici işletmeler ile tüketicileri bir araya getiren bir pazar niteliğindedir. Bu fuarların belirli bir tema içerisinde kurulmuş olması işletmeleri doğrudan hedef kitlelerine ulaştırmakta ve işletmelere kendilerini tanıtma, ürünlerini pazarlama imkânı sağlamaktadır. İhtisas fuarları, fuarın organize edildiği sektör noktasında, aynı sektörde faaliyet gösteren bir çok işletmeyi de bir araya getirmektedir. Böylece bu işletmeler arasında bilgi alışverişlerinin yapılması, geleceğe yönelik tahminlemelerin yapılması ve işletmeler arasında ikili anlaşmaların yapılmasını da sağlamaktadır. Benzer şekilde aynı sektörde faaliyet göstermek isteyen katılımcılarda bu fuarlara katılmakta ve işletmeler bu katılımcılara kendi ürün ve hizmetlerini tanıtma ve pazarlama firsatı yakalamaktadırlar (https://www.marmarafuar.com.tr/fuarlarin-onemi/, 2018).

Entegre Fuarlar; ana bir ürünle ilgili diğer ürün, mamul, yarı mamul, ekipman ve hammadde gibi temel ve yan dalları kapsayacak şekilde entegre edilerek düzenlenen etkinliklerdir. Örneğin, Danimarka'da düzenlenen sütçülük ve süt ürünleri fuarı, yeme teknolojisi, süt verimi artış örnekleri gibi konularda tüm yan dalları da kapsadığından entegre fuarlara örnektir (Aksu vd., 2013: 273).

Tüketici Fuarlarl; toplumun her kesimine açık şeklinde olan hem de tüketim mallarının sergilendiği fuarlar halinde ortaya çıkmaktadır (Tuerxun, 2017:3). Katılımcı ve ziyaretçilerin genellikle fuarın düzenlendiği merkezde ya da yakın komşu merkezlerden gelen halkın oluşturduğu fuarlardır. Tüketici fuarlarının, toplumdan her kesimine açık olması, hem merkez hem de komşu ülkelerden ziyaretçilere ulaşılabilmesini sağlayarak fuarın verimliliğini arttırmaktadır. Katılımcıların daha çok fayda sağlayabilmeleri için, bu fuarlara ürünlerini satan perakendecilerle birlikte katılım göstermeleri önemlidir (Acartürk, 2013: 6).

\section{ULUSLARARASI PAZARLAR AÇISINDAN FUARLARIN ÖNEMI}

Günümüzde müşterilerle kurulacak olan yakın ilişkiler, ulusal ve uluslararası pazarda başarı için önemli bir unsur haline gelmiştir. Bu açıdan bakıldığında fuar organizasyonları, müşteri ile doğrudan iletişim kurulabilmesini ve satış yapılabilmesini sağlayan önemli bir satış geliştirme aracıdır.

Fuar organizasyonları etkin bir iletişim ve satış kanalı olmalarının yanı sıra, işletmelerin ürün ve fiyat politikalarını da etkilerler ve gelişen teknoloji ve uygulamalarla birlikte değişim gösterirler. Fuar organizasyonları iki amaca hizmet etmektedir: Bunlardan birincisi, işletmeler açısından hem ürünlerini müşterilerine tanıtmalarını hem de ticari anlaşmalar yapmalarını sağlayan bir pazarlama aracıdır. İkinci ise, ortaya çıkardığı sıcak ortam ile satışların ve profesyonel ağların gelişmesine yardımcı olur. İşletmenin ve işletmenin sunduğu ürünlerinin tanıtımına ilave olarak, neredeyse hiçbir pazarlama aracı fuarlar kadar müşteri ile yüz yüze iletişim kurma özelliğine sahip değildir (Cengiz ve Yücel, 2017: 74).

Fuar organizasyonları satış ekiplerinin ulaşamadığı müşteri kitlelerine ulaşım sağlamaktadır. Ziyaretçilerin stantlarda ortalama 22 dakika kaldığ 1 ve katılan ziyaretçilerin \% 85'inin nihai satın alma kararlarını fuarlar sayesinde aldıkları ortaya çıkmıştır. Bireysel satış ziyaretlerine göre fuar organizasyonlarına katılım maliyet açısından daha uygundur ve etkin bir tanıtım açısından da bireysel tanıtımlardan sonra en önemli ikinci tanıtım aracıdır. Alman Fuarcılık 
Sanayii Derneği (AUMA), fuarların işletmelere ve ziyaretçilere sunduğu firsatları ve sağladı̆̆ faydaları Tablo 1'de özetlemektedir:

Tablo 1. Fuarların Katılımcı İşletmelere ve Ziyaretçilere Sunduğu Fırsatlar

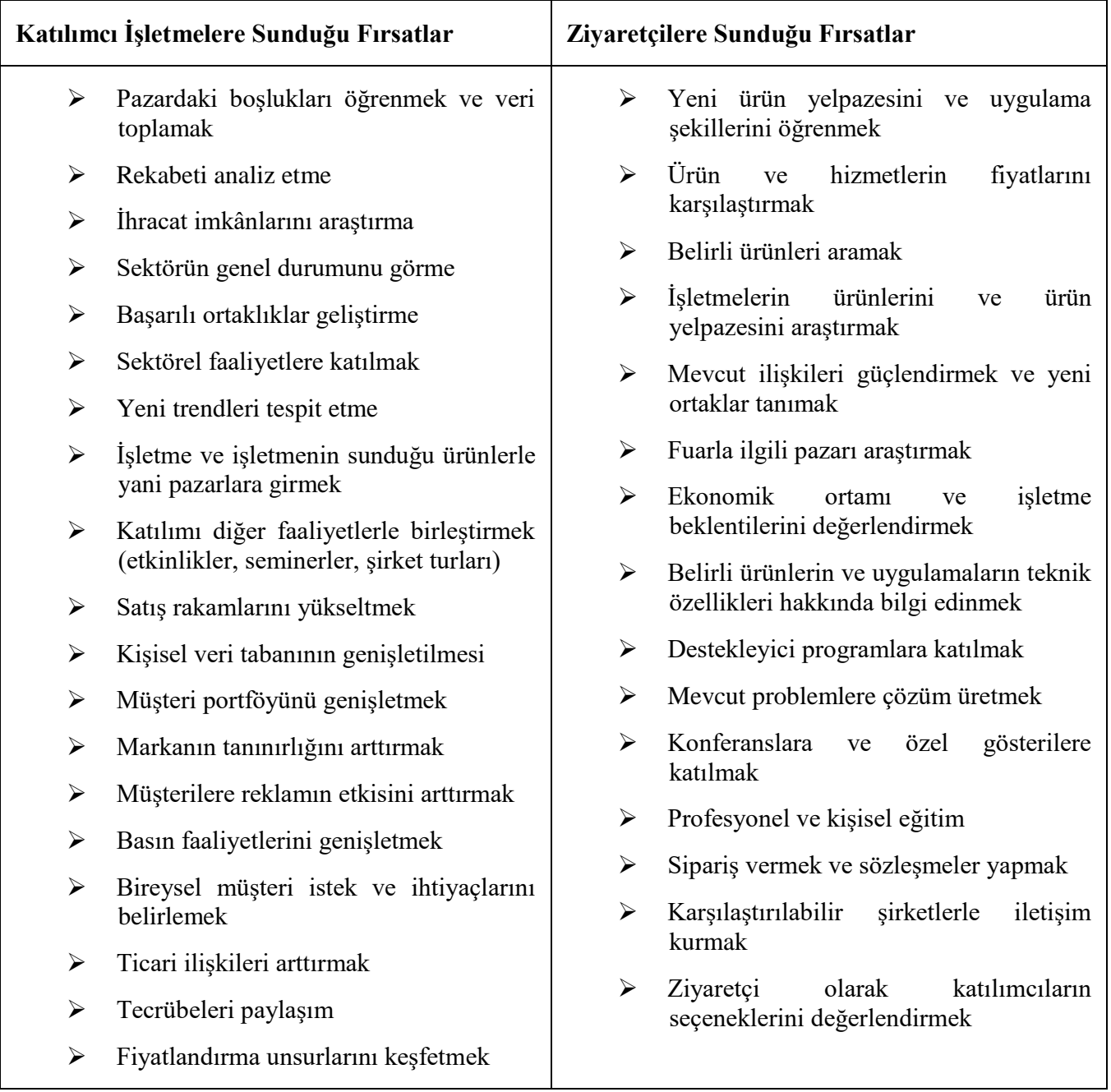

Kaynak: Cengiz ve Yücel, 2017: 74

\section{TURIZMM İŞLETMELERININ FUARLARA KATILIM AMAÇLARI}

İşletmelerin fuara katılım amaçları satış odaklı amaçlar ve satış odaklı olmayan amaçlar olmak üzere ikiye ayrılmaktadır. Satış odaklı amaçlar işletmenin fuara katılım sürecini pazarlama faaliyetlerinin bir parçası olarak ele aldığının bir göstergesidir. Diğer taraftan satış odaklı olmayan amaçlar ekseninde fuara iştirak eden işletmelerin, süreci kurumsal iletişim sürecinin bir alt öğesi olarak değerlendirdiği ifade edilebilir. Bununla birlikte, fuara farklı şekillerde katılım gösteren işletmelerin kendilerini tanıtma, yeni üretmiş oldukları ürün ve hizmetler hakkında bilgi vermek, yeni bağlantılar kurmak, rakipler ve tedarikçiler hakkında 
bilgi toplamak, gelişmeleri takip etmek vb. ortak amaçları olduğu söylenebilir (Çoban ve Güzel, 2018: 540). İşletmelerin fuarlara katılım amaçları Tablo 2'de gösterilmektedir.

Tablo 2. Firmaların Fuarlara Katılım Amaçları

\begin{tabular}{|c|c|c|}
\hline & Doğrudan Satışla İlgili Amaçlar & $\begin{array}{c}\text { Doğrudan Satışla İlgili Olmayan } \\
\text { Amaçlar }\end{array}$ \\
\hline $\begin{array}{c}\text { Mevcut } \\
\text { Müşteriler }\end{array}$ & $\begin{array}{l}\text { I İlișkiyi devam ettirmek, } \\
\text { güçlendirmek } \\
>\text { Ana müșterilere gerekli mesajı } \\
\text { vermek } \\
>\text { Yeni satıș anlașmaları yapmak }\end{array}$ & $\begin{aligned} & \text { Var olan imajı muhafaza etmek } \\
> & \text { Urünleri tanıtmak, denemek } \\
> & \text { Rakip firmalar hakkında bilgi } \\
& \text { toplamak ve pazar araștırması } \\
& \text { yapmak } \\
> & \text { Șirket ve ürünleri pazarda } \\
& \text { tanıtmak }\end{aligned}$ \\
\hline $\begin{array}{l}\text { Potansiyel } \\
\text { Müşteriler }\end{array}$ & $\begin{aligned} &> \text { Muhtemel müșterilerle iletișim ve } \\
& \text { bağlantı kurmak } \\
&>\text { Firmanın ürünlerine olabilecek } \\
& \text { muhtemel talebi belirlemek } \\
&>\text { Muhtemel müșterilere ürün ve } \\
& \text { firmayla ilgili olarak gerekli } \\
& \text { mesajları vermek } \\
&>\text { Potansiyel müșterileri belirleyip } \\
& \text { kaydını tutmak } \\
&>\text { Șirketin faaliyet alanını ve ürünün } \\
& \text { pazar payını genișletmek } \\
&>\text { Yeni acenteler ve distribütörler } \\
& \text { bulmak }\end{aligned}$ & $\begin{aligned} & \text { İletișim kurmak } \\
> & \text { Yeni imaj yaratmak } \\
> & \text { Bilgi toplamak } \\
> & \text { Muhtemel rakipler hakkında } \\
& \text { bilgi toplamak } \\
> & \text { Değișen pazar koșulları } \\
& \text { hakkında bilgi toplamak }\end{aligned}$ \\
\hline
\end{tabular}

Kaynak: T.C. Millî Eğitim Bakanlığı (2018). Megep, Halkla İlişkiler ve Organizasyon Hizmetleri, Katılımcı Firma Fuar Öncesi Hazırlıkları, s.15

Tütüncüoğlu (2009: 17-20), işletmelerin fuarlar sayesindeki kazanımlarını aşağıdaki şekilde özetlemiştir.

- Fuarlara katılımla birlikte, işletmeler kurumsal kimliklerini güçlendirebilirler.

- İşletmeler prestij sağlamak amacıyla fuarlara katılabilirler.

- İşletmeler müşterilerinin kendiler hakkındaki görüş ve düşüncelerini yüz yüze iletişim kurarak öğrenebilirler.

- İşletmeler, fuarlar sayesinde yeni müşteri kazanırlar ve mevcut müşterileriyle de ilişkilerini geliştirirler.

- İşletmeler ürün ve hizmetlerini fuarlar sayesinde potansiyel müşterilerine doğrudan tanitma firsatı yakalarlar.

- Fuarlara katılımla birlikte işletmeler yeni iş bağlantıları kurabilir ve yeni müşterilere ulaşabilirler.

- İşletmeler Pazar araştırmalarını fuarlar vesilesiyle sağlayabilirler.

- Fuarlar, işletmelerin pazara sunacakları yeni ürünlerin kalite standartları, teknik özellikleri, fiyatlandırılması ve dağıtım kanalları gibi hususlar hakkında yeni stratejiler sunmasina yardimci olur. 
- İşletmeler piyasaya sürdükleri yeni ürünlerin kabul edilebilirlik durumunu fuarlar sayesinde öğrenebilirler.

- İşletmeler karlılıklarını fuarlara katılarak arttırabilirler.

- İşletmeler pazardaki gerçek konumlarını öğrenmek için fuarlara katılabilirler. Bu sayede de rakiplerini de analiz ederek bilgi toplayabilirler.

- İşletmeler, kendileri ile aynı sektörde yer alan diğer işletmelerle yeni iş ortaklıkları kurma noktasında fuarlardan faydalanabilirler.

- Fuarlar sayesinde işletmeler medyada yer alır ve kendi ürün ve hizmetlerini tanıtma firsatı yakalar.

- İşletmeler fuarlarda ihracat firsatlarını yakalayarak önemli kazanımlar sağlayabilirler.

- İşletmelerin fuarlar için ayırdıkları bütçe, etkin bir tanıtım olarak işletmeye geri dönüş sağlar.

- Fuarlar, ülke ekonomisine katkı sağlar. Buna bağlı olarak da ekonomi canlanır ve işletmelerin de satışları ve kârlılıkları artabilir.

\section{YÖNTEM}

\subsection{Araştırmanın Amacı}

$\mathrm{Bu}$ araştırmanın amacı ulusal ve uluslararası turizm fuarlarına katılan turizm işletmelerinin fuarlara katılım amaçlarını belirlemek ve fuarların pazarlama faaliyetleri açısından önemini ortaya koymaktır. Bu amaca yönelik olarak literatür incelemesine dayalı ürün ve hizmet tanıtımı, doğrudan satış, müşteri/bayi ağını genişletme, rakip analizi, marka/kurumsal itibar kazanma ve yeniliklerin takibi şeklinde 6 temel katılım amacı belirlenmiştir. $\mathrm{Bu}$ amaç doğrultusunda aşağıdaki araştırma sorularına cevap aranacaktır:

Araştırma Sorusu 1: Turizm işletmeleri öncelikli olarak hangi amaçları gerçekleştirmek için fuarlara katılım göstermektedir?

Araştırma Sorusu 2: Fuarlara katılım amaçları turizm işletmelerinin türlerine göre anlamlı bir farklılık göstermekte midir?

\subsection{Araştırmanın Önemi}

Fuar organizasyonları günümüzde işletmeler açısından en önemli pazarlama faaliyetlerinden birisidir. İşletmeler müşterileri ve rakipleriyle doğrudan iletişime geçmekte ve yeni ürün ve hizmetleri de fuarlar sayesinde takip etmektedir. Sayısı her geçen gün artan fuar organizasyonlarının katılımıı işletmeler açısından önemi de git gide artmaktadır. Bu nedenle işletmelerin fuarlara katılım amaçlarının ve katılım sonuçlarının incelenmesi gerekmektedir.

\subsection{Araştırmanın Evreni ve Örneklemi}

Araştırma evrenini 7-10 Aralık 2017 tarihleri arasında İzmir'de düzenlenen Travel Turkey İzmir fuarına katılan işletmeler oluşturmaktadır. Fuara 36 ülke ile 54 ilden bin 284 katılımcı yer almıştır ve fuar 44 bin 589 kişi tarafından ziyaret edilmiştir. Katılımcıların 54'ü illerin tanıtım standı olması ve pazarlama faaliyetlerinin bulunmaması dolayısıyla araştırma kapsamı dışında tutulmuş, araştırmaya 230 katılımeı işletme dahil edilmiştir. Zaman kısıtı ve işletmelerin yoğunluğu dolayısıyla örnekleme yöntemine başvurulmuş ve kararsal örnekleme 
yöntemi ile belirlenen 70 firma üzerinde araştırma gerçekleştirilmiştir. Örneklemin evrene oran $1 \% 28$ 'dir.

\subsection{Verileri Toplama Yöntemi}

Araştırmada veri toplama aracı olarak anket tekniği kullanılmıştır. Anketler işletme çalışanlarına ve yöneticilerine fuar sırasında yüz yüze görüşme yöntemi ile toplanmıştır. Araştırmada kullanılan anket formu iki bölümden oluşmaktadır. Anket formunun ilk bölümünde işletme çalışanlarının ve işletmelerin özelliklerini belirlemeye yönelik olarak hazırlanan 11 soru bulunmaktadır. Anket formunun ikinci bölümü, işletmelerin fuarlara katılım amaçlarını belirlemeye yönelik 5'li Likert ölçeğine göre hazırlanan toplam 27 adet önerme şeklinde ifadeden oluşmaktadır. Bu ifadelerden 5 adedi işletmelerin ürün ve hizmet tanıtımlarına yönelik, 4 adedi doğrudan satışlarına yönelik, 4 adedi müşteri/bayi ağını genişletmeye yönelik, 5 adedi rakip analizine yönelik, 5 adedi marka/kurumsal itibar kazanmaya yönelik ve 4 adedi de yenilik takibine yöneliktir. Ölçekteki ifadelerin hazırlanmasında Çoban (2014), Torun vd. (2012) ve Lee ve Kim (2008) çalışmalarından faydalanılmıştır. Verilerin analizinde SPSS paket programı kullanılmıştır.

\section{BULGULAR VE YORUMLAR}

\section{1. İşletmelerin Özelliklerine İlişskin Bulgular}

Tablo 3. İşletmelerin Özelliklerine İlişsin Bulgular

\begin{tabular}{|l|l|c|c|}
\hline \multicolumn{2}{|c|}{ Değişkenler } & Sıklık (n) & Yüzde Değeri (\%) \\
\hline İşletmenin Faaliyet Süresi & $1-5$ yıl & 22 & 31.40 \\
\hline & $6-10$ yıl & 16 & 22.90 \\
\hline & $11-15$ yıl & 12 & 17.10 \\
\hline & 16 yıl ve üzeri & 20 & 28.60 \\
\hline İşletmenin Faaliyet Konusu & Toplam & 70 & 100.00 \\
\hline & Seyahat Acentası & 30 & 42.90 \\
\hline & Otel İşletmesi & 29 & 41.40 \\
\hline & Havayolu İşletmesi & 3 & 4.30 \\
\hline & Yiyecek-I̧ecek İşletmesi & 8 & 11.40 \\
\hline Stant Düzenleme Sorumlusu & Toplam & 70 & 100.00 \\
\hline & İşletmenin Kendisi & 47 & 67.1 \\
\hline & Organizasyon Şirketi & 23 & 32.9 \\
\hline Devlet Teşviki Kullanımı & Toplam & 70 & 100.00 \\
\hline & Evet & 21 & 30.00 \\
\hline & Hayır & 34 & 48.60 \\
\hline & Bilgim Yok & 15 & 21.40 \\
\hline $\begin{array}{l}\text { Teşvik Kullanımının Katılıma } \\
\text { Etkisi }\end{array}$ & Toplam & 70 & 100.00 \\
\hline & Evet & 31 & 44.30 \\
\hline & Hayır & 21 & 30.00 \\
\hline & Bilgim Yok & 18 & 25.70 \\
\hline $\begin{array}{l}\text { Y1lda Katılımı Gerçekleştirilen } \\
\text { Fuar Sayıs1 }\end{array}$ & Toplam & 70 & 100.00 \\
\hline & 1 & 10 & 14.30 \\
\hline & 2 & 8 & 32.90 \\
\hline & 3 & & 14.30 \\
\hline & 4 & 23.40 \\
\hline
\end{tabular}




\begin{tabular}{|l|l|c|c|}
\hline & 5 ve üzeri & 19 & 27.10 \\
\hline & Toplam & 70 & 100.00 \\
\hline Fuar Seçimindeki Kriter & Devlet Teşvikleri & 8 & 11.40 \\
\hline & Ülke & 8 & 11.40 \\
\hline & Fuarın İmaj1 & 37 & 52.90 \\
\hline & Fuar Ziyaretçi Sayı1 1 & 15 & 21.40 \\
\hline & Güvenilirlik & 2 & 2.90 \\
\hline & Toplam & 70 & 100.00 \\
\hline
\end{tabular}

Tablo 3'de katılımcı turizm işletmelerinin özellikleri incelendiğinde \%31.4'ünün 1-5 yıl arası, $\% 28.6$ 'sının 16 yıl ve üzeri, \%22.9'unun 6-10 yıl arası ve \%17.1'inin 11-15 yıl arası faaliyet süresinin bulunduğu görülmektedir. Katılımcıların \%42.9'unu seyahat acentaları, 41.4'ünü otel işletmeleri, 11.4'ünü yiyecek içecek işletmeleri ve \%4.3'ünü havayolu işletmeleri oluşturmaktadır. Katılımcıların \%67.1'i fuar stant düzenlemesi kendilerinin organize ettiğini, \%32.9'u ise fuar stant düzenlemesi konusunda bir organizasyon şirketi ile anlaştığını beyan etmiştir. İşletmelerin \%48.6'sının fuarlara katılımda devlet teşviki kullanmadığını, \%30'u devlet teşviki kullandığını, \%21.4'ü ise devlet teşviki konusunda bilgisinin olmadığını belirtmişlerdir. "Devlet teşvikleri fuarlara katılımınızı etkiliyor mu?" sorusuna \%44.3'ü evet cevabını, \%30'u hayır cevabını ve \%25.7'sinin de bilgisinin olmadı̆̆ cevabını vermişlerdir. İşletmelerin \%32.9'u yılda 2 fuara, 27.1'i en az 5 fuara, \%14.3'ü yılda 1 fuara, \%14.3'ü yılda 3 fuara ve $\% 11.4$ 'ü yılda 4 fuara katılmaktadır. İşletmelerin fuar seçimlerini etkileyen unsurlar \%52.9 ile fuarın imajı, \%21.4 ile fuarın ziyaretçi sayısı, \%11.4 ile fuarın düzenlendiği ülke ve sağlanan devlet teşvikleri ve \%2.9 ile fuarın güvenilirliği olarak ortaya çıkmaktadır.

\subsection{Araştırma Ölçeğinin Güvenilirliği ve Geçerliliği}

Araştırmada öncelikle kullanılan ölçeğin güvenilirlik ve geçerlilik analizleri yapılmıştır. Ölçeğin güvenilirlik ve geçerliliğine ilişkin hesaplanan değerler Tablo 4'te gösterilmektedir.

Tablo 4. Araştırma Ölçeğinin Güvenilirlik ve Uyușma Geçerliliği Sonuçları

\begin{tabular}{|c|c|c|c|c|c|}
\hline Faktörler & Maddeler & $\begin{array}{l}\text { Faktör } \\
\text { Yükleri }\end{array}$ & $\begin{array}{c}\text { Cronbach } \\
\alpha\end{array}$ & $C R$ & $A V E$ \\
\hline \multirow{5}{*}{$\begin{array}{l}\text { Ürün ve } \\
\text { Hizmet }\end{array}$} & $\begin{array}{l}\text { Fuarlar işletmemizin ürün ve } \\
\text { hizmetlerini tanıtmaya yardımcı } \\
\text { olmaktadır }\end{array}$ & 0.835 & \multirow{5}{*}{0.801} & \multirow{5}{*}{0.863} & \multirow{5}{*}{0.558} \\
\hline & $\begin{array}{l}\text { Fuarlar ürün ve hizmetlerimizi } \\
\text { iyilestirmede katkı sağlamaktadır }\end{array}$ & 0.730 & & & \\
\hline & $\begin{array}{l}\text { Fuar sırasında ziyaretçilerin ürün ve } \\
\text { hizmetlerle ilgili görüşleri } \\
\text { alınmaktadır }\end{array}$ & 0.759 & & & \\
\hline & $\begin{array}{l}\text { Fuara gelen ziyaretçilere ürün ve } \\
\text { hizmetlerimizle ilgili küçük } \\
\text { hediyeler verilmektedir }\end{array}$ & 0.664 & & & \\
\hline & $\begin{array}{l}\text { Fuar sırasında üretilmesi planlanan } \\
\text { ürün ve hizmetlerin sahip olması } \\
\text { gereken özellik, fayda ve standartlar } \\
\text { hakkında bilgiler toplamaktadır. }\end{array}$ & 0.740 & & & \\
\hline & $\begin{array}{l}\text { Fuarlar işletmemize doğrudan satış } \\
\text { imkânı tanımaktadır }\end{array}$ & 0.701 & & & \\
\hline & Fuarlar isletmemizin satıslarını & 0.791 & & & \\
\hline
\end{tabular}


GÜVEN \& CEYLAN

\begin{tabular}{|c|c|c|c|c|c|}
\hline \multirow{3}{*}{$\begin{array}{l}\text { Doğrudan } \\
\text { Satış }\end{array}$} & arttırmaktadır. & & \multirow[t]{3}{*}{0.669} & \multirow[t]{3}{*}{0.801} & \multirow[t]{3}{*}{0.504} \\
\hline & $\begin{array}{l}\text { Fuarlar müşteri ve işletmelerle yüz } \\
\text { yüze iletişim kurma imkânı } \\
\text { sağlamaktadır }\end{array}$ & 0.740 & & & \\
\hline & $\begin{array}{l}\text { Fuarlar sayesinde aracı işletmelere } \\
\text { olan bağlılığımız azalmaktadır }\end{array}$ & 0.595 & & & \\
\hline \multirow{4}{*}{$\begin{array}{l}\text { Müşteri/Bayi } \\
\text { Ağ1 } \\
\text { Genişletme }\end{array}$} & $\begin{array}{l}\text { Fuarlar yeni müşteriler kazanmamızı } \\
\text { sağlamaktadır }\end{array}$ & 0.821 & \multirow{4}{*}{0.864} & \multirow{4}{*}{0.907} & \multirow{4}{*}{0.711} \\
\hline & $\begin{array}{l}\text { Fuarlar müşteri istek ve ihtiyaçlarını } \\
\text { öğrenmemizi sağlar }\end{array}$ & 0.901 & & & \\
\hline & $\begin{array}{l}\text { Fuarlar yeni distribütör ya da acenta } \\
\text { bulmamıza yardımcı olmaktadır }\end{array}$ & 0.815 & & & \\
\hline & $\begin{array}{l}\text { Fuarlar yeni pazarlara açılmamıza } \\
\text { firsat sağlamaktadır }\end{array}$ & 0.835 & & & \\
\hline \multirow{5}{*}{ Rakip Analizi } & Fuarlar rekabet avantajı sağlar & 0.746 & \multirow{5}{*}{0.780} & \multirow{5}{*}{0.879} & \multirow{5}{*}{0.496} \\
\hline & $\begin{array}{l}\text { İ́şletmemiz fuar esnasında } \\
\text { tedarikçileri ziyaret ederek } \\
\text { tedarikçilerin sunmuş olduğu yeni } \\
\text { ürün ve hizmetleri takip etmektedir. }\end{array}$ & 0.693 & & & \\
\hline & $\begin{array}{l}\text { İşletmemiz fuar alanında düzenlenen } \\
\text { konferanslara katılarak sektör } \\
\text { hakkında güncel gelişmeleri takip } \\
\text { etmektedir. }\end{array}$ & 0.826 & & & \\
\hline & $\begin{array}{l}\text { İ̧şletmemiz fuar esnasında rakip } \\
\text { işletmelerin kurumsal iletişim } \\
\text { stratejileri hakkında bilgi } \\
\text { toplamaktadır. }\end{array}$ & 0.679 & & & \\
\hline & $\begin{array}{l}\text { İşletmemiz fuar öncesinde fuara } \\
\text { katılacak rakipleri hakkında ön } \\
\text { araştırma yapmaktadır }\end{array}$ & 0.702 & & & \\
\hline \multirow{6}{*}{$\begin{array}{l}\text { Marka/Kurums } \\
\text { al İtibar } \\
\text { Kazanma }\end{array}$} & $\begin{array}{l}\text { Fuarlar işletmemizin imaj } \\
\text { yönetimini kolaylaştırır }\end{array}$ & 0.837 & \multirow{5}{*}{0.798} & \multirow{5}{*}{0.896} & \multirow{5}{*}{0.506} \\
\hline & $\begin{array}{l}\text { İşletmemiz fuarı ziyaret eden önemli } \\
\text { sektör aktörleri ya da politik } \\
\text { aktörlerle görüşmeler } \\
\text { gerçekleştirmekte ve bu aktörlerin } \\
\text { stantta ağırlanması için çaba } \\
\text { harcamaktadır. }\end{array}$ & 0.696 & & & \\
\hline & $\begin{array}{l}\text { Fuarlarda ziyaretçilere işletmemizin } \\
\text { imajına katk1 sağlayacak hediyeler } \\
\text { verilmektedir. }\end{array}$ & 0.762 & & & \\
\hline & $\begin{array}{l}\text { Fuarlara katılım işletmenin vizyon } \\
\text { ve misyonuna katkıda } \\
\text { bulunmaktadır. }\end{array}$ & 0.800 & & & \\
\hline & $\begin{array}{l}\text { İşletmemiz kurum kimliği ve kurum } \\
\text { imajını destekleyen stant tipini (Ara } \\
\text { koridor, köşe, yarımada, ada vb.) } \\
\text { seçmektedir. }\end{array}$ & 0.620 & & & \\
\hline & $\begin{array}{l}\text { Fuarlar uluslararası pazarda yeni } \\
\text { trendleri ve teknolojileri takip } \\
\text { etmemizi sağlamaktadır }\end{array}$ & 0.881 & & & \\
\hline
\end{tabular}


ALANYA AKADEMIKK BAKIŞ DERGİSİ 3/3 (2019)

\begin{tabular}{|c|c|c|c|c|c|}
\hline \multirow[t]{3}{*}{ Yenilik Takibi } & $\begin{array}{l}\text { Fuarlar işletmemizin yeni } \\
\text { ürün/hizmet geliştirmesine katk1 } \\
\text { sağlar }\end{array}$ & 0.754 & \multirow[t]{3}{*}{0.792} & \multirow[t]{3}{*}{0.866} & \multirow[t]{3}{*}{0.620} \\
\hline & $\begin{array}{l}\text { Fuarlara katılım ile müşterilerimizin } \\
\text { ürün ve hizmetlerle ilgili yenilik } \\
\text { beklentilerini karş1layabilmekteyiz. }\end{array}$ & 0.829 & & & \\
\hline & $\begin{array}{l}\text { Fuarlar inovatif şirket olma yolunda } \\
\text { bize imkân sağlamaktadır }\end{array}$ & 0.672 & & & \\
\hline \multicolumn{6}{|c|}{ Genel Cronbach $\alpha: 0.947$} \\
\hline
\end{tabular}

Ölçeğin güvenilirliğinin belirlenmesinde iç tutarlılık katsayısı'nın (Cronbach $\alpha$ ) yanı sıra bileşik güvenilirlik ve açıklanan ortalama varyans (AVE) değerlerine bakılmıştır. Ölçeğin Genel Cronbach $\alpha$ değeri 0.947 olarak hesaplanmıştır. Faktörlerin Cronbach $\alpha$ değerlerine bakıldığında, sadece doğrudan satış faktörünün Cronbach $\alpha$ değerinin 0.70 değerinden biraz düşük olduğu görülmektedir. Ancak diğer güvenilirlik değerleri belirlenen sınır değerlerinin üzerinde olduğundan $(\mathrm{CR}>0.70$ ve $\mathrm{AVE}>0.50)$ bu faktör ölçekten çıkarılmamıştır. Diğer faktörlerin ise Cronbach $\alpha$ değerlerinin 0,80 ' den büyük olduğu görülmektedir. CR ve AVE değerlerine bakıldığında ise rakip analizi faktörünün AVE değerinin sınır değerinin biraz altında olduğu görülmüştür. Bu faktörün diğer güvenilirlik değerleri (Cronbach $\alpha$ ve $\mathrm{CR}$ ) belirlenen sınır değerlerinin üzerinde olduğundan, bu faktörün de ölçekten çıkarılmamasına karar verilmiştir. Buna göre ölçeğin güvenilirlik kriterlerini karşıladığı söylenebilir.

Ölçeğin geçerliliği ise yapı geçerliliği (uyuşma ve ayrışma geçerliği) yönünden incelenmiştir. Uyuşma geçerliliği için öncelikle faktör yüklerine bakılmıştır. Her bir faktör yükünün ideal değerinin 0.70 veya üzeri değer olması ve en düşük faktör yükü değerinin ise 0,50 olmas1 gerekmektedir. (Hair vd. 2009). Faktör yüklerinin yüksek olması ve ait oldukları faktöre anlamlı bir şekilde yüklenmiş olması, ölçeğin uyuşma geçerliliğinin yüksek olduğunun göstergesi olarak kabul edilmektedir. Tablo 4 incelendiğinde, her bir gözlenen değişkene ait faktör yüklerinin 0,50 değerinden büyük oldukları ve ait oldukları faktöre anlamlı bir şekilde yüklendikleri görülmektedir. Uyuşma geçerliliği için ayrıca AVE ve CR değerlerine de bakılmıştır. Uyuşma geçerliliği için AVE değerinin 0.50 değerinden yüksek olması, aynı zamanda CR değerinin ise AVE değerinden yüksek olması gerekmektedir (Hair vd.,2009). Fornell ve Larcker (1981) ise değişkenlere ait AVE değerlerinin 0.50 değerinin üstünde olmasının uyuşma geçerliliğinin sağlandığına dair ek kanıt olduğunu ifade etmişlerdir. Tablo 4'de görüldüğü üzere her bir faktörün CR değeri AVE değerinden büyük olmakla birlikte rakip analizi faktörünün AVE değerinin eşik değer olan 0.50 değerinin biraz altında kaldığ1 görülmektedir. Daha önce belirtildiği üzere, öteki güvenilirlik ölçümleri yeterli düzeyde olduğunda AVE değerinin 0.5 değerinden biraz düşük olması kabul edilebilmektedir. Dolayısıyla ölçeğin uyuşma geçerliliği yönünden gerekli ölçütleri sağladıği görülmektedir.

Uyuşma geçerliliğinden sonra ölçek ayrışma geçerliliği yönünden incelenmiştir. Ayrışma geçerliliğinin sağlanabilmesi için bir yapıyı ölçen ölçekle, farklı yapıları ölçmek için kullanılan ölçekler arasında zayıf bir ilişkinin yani düşük korelasyonun olması gerekmektedir (Altunışık vd., 2010:122). Fornell ve Larcker (1981:46) ise ayrışma geçerliliğinden bahsedilebilmesi için her bir yapıya ait hesaplanan AVE değerinin, her bir yapının diğer yapılarla olan korelasyonlarının karesinden büyük olması gerektiğini ifade etmişlerdir. 
Tablo 5. Araştırma Ölçeğinin Ayrışma Geçerliliği Analizi Sonuçları

\begin{tabular}{|l|l|c|c|c|}
\hline \multicolumn{1}{|c|}{ Faktör1 } & \multicolumn{1}{|c|}{ Faktör 2 } & Korelasyon & $\begin{array}{c}\text { Korelasyon } \\
\text { Karesi }\end{array}$ & $\begin{array}{c}\text { Faktör1 } \\
\text { AVE }\end{array}$ \\
\hline Ürün ve Hizmet & Doğrudan Satış & 0.504 & 0.254 & \\
& Müşteri/Bayi Ağı Genişletme & 0.327 & 0.107 & 0.558 \\
& Rakip Analizi & 0,221 & 0.049 & \\
& Marka/Kurumsal İtibar Kazanma & 0,401 & 0.160 & \\
& Yenilik Takibi & 0.392 & 0.153 & \\
\hline Doğrudan Satış & Müşteri/Bayi Ağı Genişletme & 0.158 & 0.024 & \multirow{2}{*}{0.504} \\
& Rakip Analizi & 0.287 & 0.082 & \\
& Marka/Kurumsal İtibar Kazanma & 0.303 & 0.092 & \\
& Yenilik Takibi & 0.511 & 0.261 & \\
\hline Müşteri/Bayi Ağı & Rakip Analizi & 0.443 & 0.196 & \\
Genişletme & Marka/Kurumsal İtibar Kazanma & 0.591 & 0.349 & 0.711 \\
& Yenilik Takibi & 0.198 & 0.039 & \\
\hline Rakip Analizi & Marka/Kurumsal İtibar Kazanma & 0.314 & 0.098 & 0.496 \\
& Yenilik Takibi & 0.278 & 0.077 & \\
\hline Marka/Kurumsal İtibar & Yenilik Takibi & 0.476 & 0.226 & 0.506 \\
Kazanma & & & \\
\hline
\end{tabular}

Tablo 5'e göre, faktörler arasındaki korelasyonların tümünün pozitif ve anlamlıdır. Faktörler arasında orta ve düşük düzeyde bir korelasyon bulunmaktadır. Ayrıca hiçbir korelasyon değerinin 0.85 değerinden yüksek olmadığı diğer bir ifade ile çoklu doğrusallık bağlantısı sorununun olmadığı anlaşılmaktadır. Buna ek olarak bütün faktör yapılarına yönelik hesaplanmış olan AVE değerlerinin, o faktör yapılarının diğer faktör yapıları ile arasındaki korelasyonlarının karesinden daha büyük bir değere sahip olduğu görülmekte ve ölçeğin ayrışma geçerliliğine sahip olduğu anlaşılmaktadır.

Ölçeğin güvenilirlik ve geçerlilik analizlerinin yapılmasından sonra, araştırma sorularının cevaplanmasına yönelik analizler gerçekleştirilmiştir. Turizm işletmelerinin fuarlara katılım amaçlarının belirlenmesine yönelik yapılan analizlerin sonucu Tablo 6' da gösterilmektedir.

Tablo 6. Turizm İşletmelerinin Fuarlara Katılım Amaçları

\begin{tabular}{|c|c|c|c|c|}
\hline $\begin{array}{c}\text { Katılım } \\
\text { Amaçları } \\
\text { (Faktörler) }\end{array}$ & Maddeler & $\begin{array}{c}\text { Mad } \\
\text { de } \\
\text { Ort. }\end{array}$ & ss. & $\begin{array}{l}\text { Faktör } \\
\text { Ort. }\end{array}$ \\
\hline \multirow{6}{*}{$\begin{array}{l}\text { Ürün ve } \\
\text { Hizmet } \\
\text { Tanıtımı }\end{array}$} & $\begin{array}{l}\text { Fuarlar işletmemizin ürün ve hizmetlerini tanıtmaya } \\
\text { yardımcı olmaktadır }\end{array}$ & 4.21 & 1.048 & \multirow{5}{*}{4.018} \\
\hline & $\begin{array}{l}\text { Fuarlar ürün ve hizmetlerimizi iyileştirmede katk1 } \\
\text { sağlamaktadır }\end{array}$ & 3.93 & 0.922 & \\
\hline & $\begin{array}{l}\text { Fuar sırasında ziyaretçilerin ürün ve hizmetlerle } \\
\text { ilgili görüşleri alınmaktadır }\end{array}$ & 3.99 & 0.909 & \\
\hline & $\begin{array}{l}\text { Fuara gelen ziyaretçilere ürün ve hizmetlerimizle } \\
\text { ilgili küçük hediyeler verilmektedir }\end{array}$ & 4.03 & 1.090 & \\
\hline & $\begin{array}{l}\text { Fuar sırasında üretilmesi planlanan ürün ve } \\
\text { hizmetlerin sahip olması gereken özellik, fayda ve } \\
\text { standartlar hakkında bilgiler toplamaktadır. }\end{array}$ & 3.93 & 1.183 & \\
\hline & $\begin{array}{l}\text { Fuarlar işletmemize doğrudan satış imkânı } \\
\text { tanımaktadır }\end{array}$ & 3.57 & 1.162 & 3.722 \\
\hline
\end{tabular}




\begin{tabular}{|c|c|c|c|c|}
\hline \multirow{3}{*}{$\begin{array}{l}\text { Doğrudan } \\
\text { Satış }\end{array}$} & Fuarlar işletmemizin satışlarını arttırmaktadır. & 3.90 & 1.024 & \\
\hline & $\begin{array}{l}\text { Fuarlar müşteri ve işletmelerle yüz yüze iletişsim } \\
\text { kurma imkânı sağlamaktadır }\end{array}$ & 4.09 & 1.073 & \\
\hline & $\begin{array}{l}\text { Fuarlar sayesinde aracı işletmelere olan bağlılı̆̆ımız } \\
\text { azalmaktadır }\end{array}$ & 3.41 & 1.245 & \\
\hline \multirow{4}{*}{$\begin{array}{l}\text { Müşteri/Bayi } \\
\text { Ağ́1 } \\
\text { Genişletme }\end{array}$} & Fuarlar yeni müşteriler kazanmamızı sağlamaktadır & 4.10 & 1.083 & \multirow{4}{*}{4.042} \\
\hline & $\begin{array}{l}\text { Fuarlar müşteri istek ve ihtiyaçlarını öğrenmemizi } \\
\text { sağlar }\end{array}$ & 4.01 & 1.009 & \\
\hline & $\begin{array}{l}\text { Fuarlar yeni distribütör ya da acenta bulmamıza } \\
\text { yardımcı olmaktadır }\end{array}$ & 3.87 & 1.020 & \\
\hline & $\begin{array}{l}\text { Fuarlar yeni pazarlara açılmamıza firsat } \\
\text { sağlamaktadır }\end{array}$ & 4.19 & 0.997 & \\
\hline \multirow{5}{*}{ Rakip Analizi } & Fuarlar rekabet avantaj1 sağlar & 3.77 & 1.010 & \multirow{5}{*}{3.69} \\
\hline & $\begin{array}{l}\text { İşletmemiz fuar esnasında tedarikçileri ziyaret } \\
\text { ederek tedarikçilerin sunmuş olduğu yeni ürün ve } \\
\text { hizmetleri takip etmektedir. }\end{array}$ & 4.26 & 0.928 & \\
\hline & $\begin{array}{l}\text { İşletmemiz fuar alanında düzenlenen konferanslara } \\
\text { katılarak sektör hakkında güncel gelişmeleri takip } \\
\text { etmektedir. }\end{array}$ & 3.57 & 1.174 & \\
\hline & $\begin{array}{l}\text { İşletmemiz fuar esnasında rakip işletmelerin } \\
\text { kurumsal iletişim stratejileri hakkında bilgi } \\
\text { toplamaktadır. }\end{array}$ & 3.45 & 1.234 & \\
\hline & $\begin{array}{l}\text { İşletmemiz fuar öncesinde fuara katılacak rakipleri } \\
\text { hakkında ön araştırma yapmaktadır }\end{array}$ & 3.43 & 1.325 & \\
\hline \multirow{5}{*}{$\begin{array}{l}\text { Marka/Kurum } \\
\text { sal İtibar } \\
\text { Kazanma }\end{array}$} & Fuarlar işletmemizin imaj yönetimini kolaylaştırır & 4.06 & 1.006 & \multirow{5}{*}{3.98} \\
\hline & $\begin{array}{l}\text { İşletmemiz fuarı ziyaret eden önemli sektör aktörleri } \\
\text { ya da politik aktörlerle görüşmeler } \\
\text { gerçekleştirmekte ve bu aktörlerin stantta } \\
\text { ağırlanması için çaba harcamaktadır. }\end{array}$ & 4.00 & 0.978 & \\
\hline & $\begin{array}{l}\text { Fuarlarda ziyaretçilere işletmemizin imajına katkı } \\
\text { sağlayacak hediyeler verilmektedir. }\end{array}$ & 3.93 & 1.231 & \\
\hline & $\begin{array}{l}\text { Fuarlara katılım işletmenin vizyon ve misyonuna } \\
\text { katkıda bulunmaktadır. }\end{array}$ & 3.91 & 1.004 & \\
\hline & $\begin{array}{l}\text { İşletmemiz kurum kimliği ve kurum imajını } \\
\text { destekleyen stant tipini (Ara koridor, köşe, } \\
\text { yarımada, ada vb.) seçmektedir. }\end{array}$ & 4.00 & 1.090 & \\
\hline \multirow[t]{4}{*}{$\begin{array}{l}\text { Yenilik } \\
\text { Takibi }\end{array}$} & $\begin{array}{l}\text { Fuarlar uluslararası pazarda yeni trendleri ve } \\
\text { teknolojileri takip etmemizi sağlamaktadır }\end{array}$ & 3.91 & 1.032 & \multirow[t]{4}{*}{3.79} \\
\hline & $\begin{array}{l}\text { Fuarlar işletmemizin yeni ürün/hizmet } \\
\text { geliştirmesine katk1 sağlar }\end{array}$ & 3.79 & 1.102 & \\
\hline & $\begin{array}{l}\text { Fuarlara katılım ile müşterilerimizin ürün ve } \\
\text { hizmetlerle ilgili yenilik beklentilerini } \\
\text { karşılayabilmekteyiz. }\end{array}$ & 3.83 & 1.063 & \\
\hline & $\begin{array}{l}\text { Fuarlar inovatif şirket olma yolunda bize imkân } \\
\text { sağlamaktadır }\end{array}$ & 3.64 & 1.204 & \\
\hline
\end{tabular}

İşletmelerin fuarlara katılım amaçları incelendiğinde, en yüksek ortalamaya (4.042) sahip olan faktörün "Müşteri ve bayi ağını genişletme" faktörü olduğu görülmektedir. Dolayısıyla işletmelerin fuarlara katılımdaki öncelikli amacının müşteri ve bayi ağını genişletmek olduğu görülmektedir. Bu faktör içerisinde işletmelerin en fazla katıldıkları ifadenin "Fuarlar yeni müşteriler kazanmamızı sağlamaktadır” (ort:4.10) ifadesi olduğu görülmektedir. işletmelerin 
fuarlara katılımdaki ikinci öncelikli amacının ise Ürün ve Hizmet Tanıtımı faktörü olduğu görülmektedir. Bu faktör içerisinde işletmelerin en fazla katıldıkları ifadenin "Fuarlar işletmemizin ürün ve hizmetlerini tanıtmaya yardımcı olmaktadır" (ort:4.21) ifadesi olduğu anlaşılmaktadır. Bu faktörleri sırası ile Marka/Kurumsal İtibar Kazanma (ort:3.98), Yenilik Takibi (ort:3.79), Doğrudan Satış (ort:3.72) ve Amaçları takip etmektedir. Rakip Analizi amacı ise işletmelerin fuarlara katılım amaçları arasında en son sırada yer almaktadır (ort:3.69). Bu noktadan hareketle, çalışmanın başında ortaya konulan ilk araştırma sorusu cevaplanmış olmaktadır.

Turizm işletmelerinin faaliyet alanları (seyahat acentası, konaklama işletmesi, havayolu işletmesi, yiyecek-içecek işletmesi) ile fuarlara katılım amaçları arasında bir farklılık olup olmadığının ortaya konulması amacıyla farklılık analizi yapılmıştır. Farklılık analizinde hangi testin kullanılacağına karar vermek için ise verilerin basıklık ve çarpıklık değerlerine bakılarak normal dağılıma uygun olup olmadığı araştırılmıştır. Çarpıklık ve basıklık katsayılarının kendi standart hatalarına bölünmesi ile hesaplanan çarpıklık ve basıklık indekslerinin \pm 2 sınırları içinde 0'a yakın olması normal dağılımın varlığına kanıt olarak değerlendirilmektedir (Tabachnick ve Fidell, 2013; Demir vd., 2016: 133). Bu bağlamda her bir faktörün basıklık ve çarpıklık değerleri incelenmiş ve çarpıklık değerlerinin +1.198 ile 1.926 sınırları içerisinde değerler aldığ içerisinde yer aldığı görülmüştür. Dolayısıyla da ölçeğin çok değişkenli normallik varsayımını karşıladığından parametrik testlerden tek yönlü ANOVA testinin uygulanmasına karar verilmiştir.

Tablo 7. Turizm İşletmelerinin Faaliyet Alanları ile Fuarlara Katılım Amaçlarna Yönelik ANOVA Testi

\begin{tabular}{|c|c|c|c|c|c|c|}
\hline & $\begin{array}{l}\text { Kareler } \\
\text { Toplamı }\end{array}$ & $\begin{array}{l}\text { Kareler } \\
\text { Toplamı }\end{array}$ & $\begin{array}{c}\text { Serbestlik } \\
\text { Derecesi }\end{array}$ & $\begin{array}{c}\text { Kareler } \\
\text { ortalaması }\end{array}$ & $\mathbf{F}$ & Anlamlılık \\
\hline $\begin{array}{l}\text { Ürün ve Hizmet } \\
\text { Tanıtımı }\end{array}$ & $\begin{array}{c}\text { Grup İçi } \\
\text { Gruplar Arası } \\
\text { Toplam }\end{array}$ & $\begin{array}{c}6.771 \\
56.500 \\
63.271\end{array}$ & $\begin{array}{l}14 \\
55 \\
69\end{array}$ & $\begin{array}{l}0.484 \\
1.027\end{array}$ & 0.471 & 0.939 \\
\hline Doğrudan Satış & $\begin{array}{c}\text { Grup İçi } \\
\text { Gruplar Aras1 } \\
\text { Toplam }\end{array}$ & $\begin{array}{l}15.382 \\
47.889 \\
63.271 \\
\end{array}$ & $\begin{array}{l}14 \\
55 \\
69\end{array}$ & $\begin{array}{l}1.099 \\
0.871\end{array}$ & 1.262 & 0.261 \\
\hline $\begin{array}{l}\text { Müşteri/Bayi } \\
\text { Ağ1 Genişletme }\end{array}$ & $\begin{array}{c}\text { Grup İçi } \\
\text { Gruplar Arası } \\
\text { Toplam }\end{array}$ & $\begin{array}{l}12.297 \\
50.975 \\
63.271\end{array}$ & $\begin{array}{l}11 \\
58 \\
69\end{array}$ & $\begin{array}{l}1.118 \\
0.879\end{array}$ & 1.272 & 0.264 \\
\hline Rakip Analizi & $\begin{array}{c}\text { Grup İçi } \\
\text { Gruplar Arası } \\
\text { Toplam }\end{array}$ & $\begin{array}{l}16.166 \\
47.106 \\
63.271\end{array}$ & $\begin{array}{l}16 \\
53 \\
69\end{array}$ & $\begin{array}{l}1.010 \\
0.889\end{array}$ & 1.137 & 0.348 \\
\hline $\begin{array}{l}\text { Marka/Kurumsal } \\
\text { İtibar Kazanma }\end{array}$ & $\begin{array}{c}\text { Grup İçi } \\
\text { Gruplar Arası } \\
\text { Toplam } \\
\end{array}$ & $\begin{array}{c}9.976 \\
53.296 \\
63.271 \\
\end{array}$ & $\begin{array}{l}14 \\
55 \\
69\end{array}$ & $\begin{array}{l}0.713 \\
0.969\end{array}$ & 0.735 & 0.730 \\
\hline Yenilik Takibi & $\begin{array}{c}\text { Grup İçi } \\
\text { Gruplar Aras1 } \\
\text { Toplam } \\
\end{array}$ & $\begin{array}{c}7.589 \\
55.682 \\
63.271\end{array}$ & $\begin{array}{l}13 \\
56 \\
69\end{array}$ & $\begin{array}{l}0.584 \\
0.994\end{array}$ & 0.587 & 0.854 \\
\hline
\end{tabular}

Yapılan ANOVA testi sonuçlarına göre turizm işletmelerinin faaliyet alanları ile fuarlara katılım amaçları arasında anlamlı bir farklılığın olmadığı görülmektedir (tüm boyutlar için $\mathrm{p}>0.001$ ). Bu noktadan hareketle, çalışmanın başında ortaya konulan ikinci araştırma sorusu da cevaplanmış bulunmaktadır. Diğer bir ifade ile fuarlara katılım amaçları konaklama 
işletmeleri, seyahat acentası, havayolu işletmeleri ve yiyecek işletmelerine göre farklılaşmamaktadır.

\section{SONUÇ VE ÖNERÍLER}

Çalışmada elde edilen sonuçları aşağıdaki şekilde özetlemek mümkündür:

İşletmelerin \%48.6'sının fuarlara katılımda teşvik kullanmadığını, \%30'u teşvik kullandığını, $\% 21.4$ 'ü ise teşvikler konusunda bilgisinin olmadığını belirtmişlerdir. İlter ve Çetinkaya (2014) tarafından117 KOBİ üzerinde yapılan çalışmada; KOBİ'lerin \% 19.7'sinin ticari fuarlara katılımda fuar katılım teşviki alabileceklerini bilmedikleri, \%34.2'sinin ise ticari fuarlara katılım desteğinden kimlerin yararlanabileceği konusunda bilgi sahibi olmadıkları sonucu bulunmuştur. Bu araştırmanın sonucu, söz konusu araştırmayı destekler niteliktedir.

Fuarlara katılım hem çaba hem de finansman yönünden oldukça maliyetli bir faaliyettir. Özellikle küçük ve orta ölçekli firmalar, birkaç günlük bir organizasyon için büyük maliyetlerin altına girmeyi çoğunlukla istememektedirler. Kaldı ki, bunu isteseler dahi pek çok firma bu bedeli yalnızca öz kaynaklarıyla karşılama gücüne sahip değildir (İlter ve Çetinkaya, 2014). Özellikle KOBİ'lere çeşitli kuruluşlar tarafından fuar teşvikleri de dahil olmak üzere çeşitli destekler verilmektedir. Fuar teşviki veren kuruluşlar arasında Dış Ticaret Müsteşarlığı, Küçük ve Orta Ölçekli İşletmeleri Geliştirme ve Destekleme İdaresi Başkanlığ1 (KOSGEB) gibi kuruluşlar bulunmaktadır. Bunun yanı sıra İzmir Ticaret Odası (IZTO) 1997 yılından itibaren, her yıl yayınladığ 1 "Teşvik Verilecek Fuarların Listesi"ndeki fuarlarda stant açan ve aidat borcu olmayan üyelerine fuar teşvikleri vermektedir. IZTO, Türkiye Odalar ve Borsalar Birliği'ne bağlı oda ve borsalar içerisinde fuar teşviki veren tek kuruluş olmaktadır. Travel Turkey İzmir Fuarı hem KOSGEB hem de İzmir Ticaret Odası tarafından desteklenmektedir. KOSGEB, KOBI'‘lere en fazla 50 metre kareye kadar metre kare başına 100 TL, İzmir Ticaret Odası ise üyelerine 40 metre kareye kadar \%60 oranında teşvik imkanı sunmaktadır. $\mathrm{Bu}$ teşviklerden yararlanma imkanlarının ve kimlerin yararlanabileceğinin işletmeler tarafından bilinmesi fuarlara katılımı artırabileceği gibi işletmelerin fuarlara katılımda karşılaştıkları finansman sıkıntılarının da azaltılmasına da yardımcı olacaktır.

Katılımcıların \%67.1'i fuar stand düzenlemesi kendilerinin organize ettiğini, \%32.9'u ise fuar stand düzenlemesi konusunda bir organizasyon şirketi ile anlaştığını beyan etmiştir. Çoban ve Güzel (2018) tarafından yapılan çalışmada turizm işletmelerinin \% 41.4'ünün fuarlardaki stantlarda kendi işletme personeline, \%58.6'sının ise fuarın gerçekleştiği bölgeden istihdam edilen geçici personele görev verdiği sonucu bulunmuştur. Yazarlar, işletmelerin fuara tekil katılım göstermeleri ve stant personelini iç kaynaklardan temin etmeleri gerektiğini, bu nedenle işletmelerin; standın konumunu, stant dizaynını, standın genel görüntüsünü, stantta görev alan personel ve personelin kıyafetini titizlikle seçmelerinin önemli olduğunu ifade etmişlerdir.

İşletmelerin fuar seçimlerini etkileyen unsurların başında \%52.9 ile fuarın imajı gelmektedir. $\mathrm{Bu}$ unsuru \%21.4 ile fuarın ziyaretçi sayısı, \%11.4 ile fuarın düzenlendiği ülke ve sağlanan devlet teşvikleri ve \%2.9 ile fuarın güvenilirliği takip etmektedir. Fuarın geçmiş başarıları, bilinirliği, büyüklüğü, zamanlaması, ulaşım imkanları, katılımcıları tarafından kabul düzeyi gibi konular işletmelerin fuar seçiminde önemli faktörler olarak ön plana çıkmaktadır. Dallmeyer (2005), işletmelerin satış, pazarlama, marka veya diğer amaçlarına yönelik en uygun fuarı seçmesinin fuarın başarısı için önemli bir adım olduğunu, fuarın sektördeki önemi ve sektör olarak işletmeye uygunluğu, rakiplerin fuara katılım durumu, ziyaretçilerin 
demografik yapıları, fuar organizatörünün tecrübesinin fuar seçiminde öne çıkan diğer başlıca unsurlar olduğunu belirtmiştir.

Araştırmada elde edilen bir diğer sonuç, turizm işletmelerinin fuarlara öncelikli olarak müşteri-bayi ağını genişletmek ve ürün ve hizmetlerinin tanıtımını yapmak amacı ile katılım gösterdikleri sonucudur. Torun vd. (2012) tarafindan yapılan çalışmada işletmelerin kendilerini ve ürünlerini tanıtmak ve müşteri ağını genişleterek pazar payını artırmak amacıyla fuarlara katıldığı sonucu bulunmuştur. İlter ve Çetinkaya (2014), yaptıkları araştırmada firmaların fuarlara katılmanın kendilerine "Yeni ürünlerin tanıtımını sağlaması", "Kurum imajının gelişimine katkı sağlaması" ve "Potansiyel müşterilere ulaşmayı sağlaması" "İlgili kitlelere tanıtım mesajları iletilmesini sağlaması" konularında en yüksek düzeyde avantajlar sağlayacağına inandıkları sonucunu bulmuşlardır. Aycı (2011), yurt dışı fuara katılan KOBİ'lerin fuara katılım amaçlarına ulaşma durumunu araştırdığı çalışmada, en yüksek amaca ulaşma oranının sektördeki yenilikleri takip etmek, mal/hizmet tanıtımını yapmak, bilgi ve görgü arttırmak, rakipler hakkında bilgi toplamak, işletmenin imajını güçlendirmek ve potansiyel alıcı bulmak konularında olduğu sonucuna ulaşmıştır.

Araştırmada elde edilen bir diğer sonuç ise, turizm işletmelerinin faaliyet alanları ile fuarlara katılım amaçları arasından bir farklılığın olmadığı sonucudur. Turizm hizmetleri yapısı itibarı ile bileşik bir hizmet niteliğindedir. Üretilen turistik ürün, ister münferit, ister paket olarak pazarlansın, birleşik ürün olma ( farklı ürünlerin birleşimi ) özelliği gösterir. $\mathrm{Bu}$ nedenle turizm sektöründe faaliyet gösteren tüm işletmeler turizm hizmetlerinin niteliği gereği birbirleriyle uyumlu olma, yakın bir işbirliği ve karşılıklı yardımlaşma içinde bulunma zorunluluğu duyarlar. Bu noktada fuarlara katılım, turizm sektöründe faaliyet gösteren işletmelere oldukça önemli avantajlar sunmakta ve hem pazarlama hem de tanıtım aktivitelerini bir arada yürütmelerine olanak sağlamaktadır. Fuar organizasyonları çok sayıdaki firmayı bir araya getirerek ortak amaçların gerçekleştirilmesi konusunda firmaların birbirleri ile iş birliği yapmalarına imkan tanımaktadır.

Fuarlar mal ve hizmet üreticilerinin ve tüketicilerinin belli bir zaman dilimi içerisinde ve belirli mekanda bir araya geldiği bir pazar olma niteliği taşımaktadırlar. Özellikle ihtisas fuarları, katılımcı işletmelerin hem satış hem de tanıtım açısından önemli kazanımlar elde etme imkanı sunarlar. Aynı zamanda fuarlar, hedef kitleye firma ve işletmenin pazarlama bileşimi hakkında bilgi verme, tanıtımı sağlama ve imajı güçlendirme konusunda önemli katkılar sunarlar. Günümüzde fuar organizasyonları reklam, halkla ilişkiler gibi çağdaş pazarlama iletişim tekniklerinden birisi haline gelmiştir. Bu faydalarına rağmen gerek karmaşık katılım süreçleri ve finansman güçlükleri ve gerekse işletmelerin fuarlara katılımın kendilerine sağlayacağı faydaları hakkında yeterince ikna olmamaları nedeni ile fuarlara katılımda işletmeler isteksiz davranabilmektedir. Fuarlara katılım kararı verilirken işletmelerin katılım amaçlarını iyi belirlemesi, fuarın hangi alıcı kitlesine hitap ettiği konusunda değerlendirme yapması, hedef pazarlarına ulaşma ve onlara doğrudan ürün satma şansını bulabilecekleri hedef pazarına ilişkin katılımcı ve ziyaretçi potansiyelinin yüksek olduğu fuarları tercih etmeleri doğru olacaktır. Ayrıca fuarın konusu, formatı, imajı, fuar organizatörünün deneyimi ve itibarı gibi faktörler de göz önünde bulundurulmalıdır. Bunun yanı sıra katılmayı düşündükleri fuarların teşvik kapsamında olup olmadığının araştırılması ve teşvik ve destek kapsamında yer alan fuarların tercih edilmesi, fuara katılımın finansmanı konusunda işletmelere yardımcı olabilecektir. 


\section{KAYNAKÇA}

ACARTÜRK, K. (2013). Fuar Organizasyonlarının Katılımcı Firmaların Finansal Performanslarına Etkileri. Yüksek Lisans Tezi, Marmara Üniversitesi Sosyal Bilimler Enstitüsü, İstanbul.

AKSU, A., YILMAZ, G. ve GÜMÜŞ, F. (2013). Örneklerle Kongre ve Fuar Yönetimi, Detay Yayıncılık, Ankara.

ALTUNIŞIK, R., COŞKUN, R., BAYRAKTAROĞLU, S. ve YILDIRIM, E. (2010). Sosyal Bilimlerde Araştırma Yöntemleri: SPSS Uygulamaları. Sakarya: Sakarya Yayıncılık.

AYCI, A. (2011). "Pazarlama Karması Açısından Yurtdışı Fuarlar: Kosgeb Yurtdışı Fuar Desteklerinden Faydalanan Kobi’lere Yönelik Bir Araştırma”. Gazi Üniversitesi İktisadi ve İdari Bilimler Fakültesi Dergisi, 13 (3), 159-182.

AYMANKUY, Y. (2006). Kongre Turizmi ve Fuar Organizasyonları, Detay Yayıncılık, Ankara.

CENGİZ, F. ve YÜCEL, E. (2017). “Pazarlama Faaliyetleri İçin Fuarların Önemi”. Journal of Travel and Tourism Research, 12, 72-80.

ÇOBAN, Ö. (2014). Konaklama İşletmelerinin Kurumsal İletişim Yönetimi Çerçevesinde Ticari Fuarlara Katılımına Yönelik Bir Model Önerisi. Doktora Tezi, Çanakkale Onsekiz Mart Üniversitesi, Sosyal Bilimler Enstitüsü, Çanakkale.

ÇOBAN, Ö. ve GÜZEL, T. (2018). “Konaklama İşletmelerinin Kurumsal İletişim Yönetimi Çerçevesinde Ticari Fuarlara Katılımına Yönelik Bir Model Önerisi”, Anemon Muş Alparslan Üniversitesi Sosyal Bilimler Dergisi, 6(4), 539-550.

DALLMEYER, B. (2005). Successful Exhibit Marketing. The Global Association of the Exhibition Industry (UFI), Paris.

DEMİ, E., SAATÇİĞLUU, Ö. ve İMROL, F. (2016). "Uluslararası Dergilerde Yayımlanan Eğitim Araştırmalarının Normallik Varsayımları Açısından İncelenmesi”. Current Research in Education, 2(3), 130-148.

FORNELL, C. ve LARCKER, D.F. (1981). "Evaluating Structural Equation Models with Unobservable Variables and Measurement Error: Algebra and Statistics". Journal of Marketing Research, 18 (3), 382-388.

HAİR, J. F., BLACK, W. C., BABİN, B. J. ve ANDERSON, R. E. (2009). Multivariate Data Analysis. NJ: Prentice Hall.

İLTER, B. ve ÇETINKAYA, M. (2014). “Kobi'lerin Ticari Fuar Teşviklerinden ve D1ş Ticaret Fırsatlarından Yararlanma Düzeyi”. Yönetim ve Ekonomi Araştırmaları Dergisi, 24, 226-249.

LE, C.H. ve KIM, S.Y. (2008). "Differential Effects of Determinants on Multi-Dimensions of Trade Show Performance: By Three Stages of Pre-Show, At-Show, and Post-Show Activities”. Industrial Marketing Management, 37(7), 784-796.

KAÇAR, E. (2013). Fuar İşletmeciliğinin Turizm Üzerine Etkileri ve Bir Model Önerisi, Yüksek Lisans Tezi, Haliç Üniversitesi Sosyal Bilimler Enstitüsü, İstanbul. 
TOKER, B. (2007). "İzmir İlinin İhtisas Fuarları Bakımından Arz Potansiyeli ve Mevcut Durumun Değerlendirilmesi”. Ege Akademik Bakış, 7(2), 421-443.

TUERXUN, Y. (2017). Uluslararası Fuarların Dış Ticaretteki Önemi: Çin ve Türkiye'de Düzenlenen Fuarlara Katılımın Değerlendirilmesi. İstanbul Ticaret Üniversitesi, Dış Ticaret Enstitüsü, Yüksek Lisans Tezi, İstanbul.

TABACHNICK, B. G. ve FIDELL, L.S. (2013). Using Multivariate Statistics, (Sixth edition). United States: Pearson Education.

TORUN, E., ÇELIKK, A. ve BOBAT, A. (2012). "Pazarlamada Fuarların Rolü ve Önemi (Yalova Süs Bitkileri İhtisas Fuarı Örneği)”. KSÜ Doğa Bil. Dergisi, 15(2), 11-21.

TÜTÜNCÜOĞLU, İ. (2009). Uluslararası Pazarlamada Bir Tutundurma Aracı Olarak Fuar ve Sergilere Katılımın Dış Ticaret Şirketleri Açısından Önemi, Yüksek Lisans Tezi, Dokuz Eylül Üniversitesi Sosyal Bilimler Enstitüsü, İzmir.

T.C. Millî Eğitim Bakanlığı, Megep, Halkla İlişkiler ve Organizasyon Hizmetleri, Katılımcı Firma Fuar Öncesi Hazırlıkları

https://www.muhasebeturk.org/ nedir/ihtisas-fuari-nedir-ne-demek 2018).

https://www.marmarafuar.com.tr/fuarlarin-onemi/, 2018).

https://www.tobb.org.tr/FuarlarMudurlugu/Documents/FUARLAR/2018fuartakvimi.xls (29.08.2018). 